Volume 3, Number 2, 2017

\title{
Energy Efficiency of Refrigerating Ejector Systems for the Condensation of Oil Product Liquid Hydrocarbons
}

\author{
Iegor Butovskyi*, Volodymyr Kogut, Volodymyr Bushmanov, Mykhailo Khmelniuk \\ Odessa National Academy of Food Technology, Educational and Scientific Institute of Refrigeration, \\ Cryotechnology and Ecoenergy, Dvorianskaya St., 1/3, Odessa, 65082, Ukraine
}

(C) 2017 Authors. Published by Lviv Polytechnic National University.

Received: September 30, 2017. Revised: October 31, 2017. Accepted: November 10, 2017.

\begin{abstract}
The oil processing enterprises are the largest consumers of fuel and energy resources, heat and electrical energy. Efficiency, rationality of their use in oil refining processes in many respects is defined by overall performance of processing equipment. Feature of processes for processing a hydrocarbon raw material is that technology processes are imperfect. One of the priority directions of increase in efficiency of energy saving of oil processing productions is the maximum use of recuperation of warmth and optimization of operating modes of technology installations. The article focuses on the use of refrigerating ejector systems at the solution of the most important problems of the oil processing industry. The offered systems allow resolving effectively issues of energy saving and rational consumption of fuel and energy resources of the oil industry enterprises. The scheme solutions in the industry are the priority direction of energy saving policy.
\end{abstract}

Keywords: refrigerating ejector systems; liquid hydrocarbons; energy efficiency; energy saving; hydrocarbon raw material.

\section{Introduction}

Annually, by different estimates, more than 1 million ton of hydrocarbons are thrown out. Specific losses of hydrocarbon only at each operation of oil draining make $1.1-1.5 \mathrm{~kg}$ per $1 \mathrm{~m}^{3}$ of the poured product.

The simple traditional low cost methods for the prevention of oil product losses (the respiratory valve, gasleveling system) are insufficiently effective. There are basic approaches to the storage of oil products by introduction of superficially active agents. However, in practice these ways have not been widely applied.

Essential source of oil resources economy is elimination of losses at their production, processing, transportation and storage. According to the specialists, using this method only, it is possible to receive up to $20 \%$ of all fuel and energy resources economy. Damage caused by these losses consists not only in the decrease in the fuel resources and cost of the lost products, but also in negative environmental effects which are caused by environmental pollution with oil products. Therefore, efforts on reduction of oil products losses give not only economic effect, but also are vital for environment protection. There is a much more negative influence of petrol stations on environment, in comparison to the other oil products storages.

It relates to the fact that, on the one hand, gas stations are placed in the large cities with a high density of buildings and considerable concentration of motor transport, and on the other hand - with the fact that emissions come from them at the height of only $2 \ldots 3 \mathrm{~m}$ above the ground. Despite quite considerable losses of gasoline due to evaporation the reservoirs of gas stations usually have no means for reduction of losses, except respiratory valves. It is impossible to apply the pontoons in them since with change of a fluid level in the reservoir the area of the fluid

" Corresponding author. Email address: ariesoon@gmail.com

This paper should be cited as: I. Butovskyi, V. Kogut, V. Bushmanov, M. Khmelniuk. Energy efficiency of refrigerating ejector systems for the condensation of oil product liquid hydrocarbons. Energy Eng. Control Syst., 2017, Vol. 3, No. 2, pp. 37 - 42. https://doi.org/10.23939/jeecs2017.02.037 
surface also changes significantly. In the conditions of petrol stations, the most preferable means of reduction of emissions of gasoline vapors to the atmosphere are systems for light fractions trapping (LFT).

Advantages of application of these installations:

- $100 \%$ decrease in technology losses of oil products due to evaporation during their transportation and storage;

- considerable reduction of emissions of harmful substances to the environment;

- maintaining of high quality of light oil products (gasoline, kerosene, diesel fuel, etc.) at their long term storage.

\section{Scopes of LFT installations based on the ejector heat exchanger}

The scopes of LFT installations based on the ejector heat exchanger are as follows

- petrol stations,

- tankers, railway tanks,

- port terminals,

- commodity oil depots,

- storages of oil products.

Definition of oil product losses in Ukraine is regulated based on the normative documents. According to the normative documents the general losses of oil products consist of natural losses at storage, reception, issue and transportation. One-time losses at accidents, repairs, etc are also included in the general losses. Natural losses are defined as a difference between the general and one-time losses.

Taking into account the peculiarity of technical and economic calculations we will consider that the most significant efficiency for defining the comparative economic efficiency of system modernization is the efficiency assessment from the point of view of reduction of losses and economic efficiency of modernization instruments $[1,2]$.

The technical and economic calculations are carried out by some authors based on the cost value of storage of one ton of oil products. And by other authors it is made on the basis of cost value of storage of oil product in $1 \mathrm{~m}^{3}$ of operational tank volume. At the same time:

$$
\begin{aligned}
& C_{n}=\frac{E}{Q}, \\
& C_{p}=\frac{E}{V},
\end{aligned}
$$

where $C_{n}$ is cost value of storage of 1 tone of oil product;

$C_{p}$ is cost value of storage of oil product in $1 \mathrm{~m}^{3}$ of operational tank volume;

$E$ is operational costs per one year;

$Q$ is turnover of the reservoir during one year;

$V$ is the maximum volume of the vapor-air mixture.

The norm of depreciation expenses for renovation from capital investments for modernization depends on normative service life of technical improvement. The positive economic effect of ejector instrument application for prevention of oil product losses is reached only if expenses for prevention of losses of 1tone of oil product are less than the total value of 1 tone of oil product.

The annual losses of gasoline due to evaporation are equal to the sum of losses due to small and big "breath". And they can be calculated according to the developed technique for each reservoir separately.

$$
P_{1}=x \cdot P_{2},
$$

where $x$ is a part of losses from the reservoir.

$$
K_{1}=P_{1} \cdot K_{s}+C_{m 1}+0.35 \cdot C_{1},
$$


where $P_{1}, P_{2}$ are annual losses of gasoline due to evaporation (they are equal to the sum of losses due to small and big "breath"); $C_{m 1}$ is the cost of mounting of system for reduction of losses due to evaporation (4-5\% of value of the losses reduction system), $\mathrm{UAH} ; C_{1}$ is the value of the system for reduction of losses due to evaporation, UAH; $K_{1}$ is the accompanying capital investments consisting of expenses for mounting and transportation of system, UAH; Ks is the specific accompanying capital investments, UAH (they are calculated based on the following ratio: for receiving 1 tone of gasoline it is necessary to spend 5 tons of crude oil).

Cost value for storage of gasoline in the reservoir equipped with system of reduction of losses is calculated by the formula:

$$
C_{r}^{p}=\frac{E_{1}}{V_{r z}},
$$

the payback period is

$$
T=\frac{K_{1}}{E_{1}-E_{2}},
$$

where $E_{1}, E_{2}$ are annual operating costs before and after modernization, respectively;

$V_{r z}$ is the reservoir volume, $\mathrm{m}^{3}$.

The calculations were carried out for the installation working with tanks of big sizes (RVS-1000, RVS-2000, RVS-3000, RVS-5000 that RVS-10000) for NPIK Zirka Ltd in the city of Zaporizhia. The calculation results are presented in tables $1 . . .3$.

\section{Results of the research work}

Table 1. Expenses for installation design.

\begin{tabular}{|l|l|c|}
\hline No & Type of activity & The cost of the performed work (UAH) \\
\hline 1 & Calculation and selection of the equipment & 4,000 \\
\hline 2 & Expert assessment & 500 \\
\hline 3 & Execution of the working draft & 6,500 \\
\hline 4 & Drawing up estimate documentation & 2,000 \\
\hline \multicolumn{2}{|l|}{ Total: } & 13,000 \\
\hline
\end{tabular}

Table 2. Expenses for installation of the equipment.

\begin{tabular}{|l|l|l|}
\hline No & The equipment from the project & Cost (UAH) \\
\hline 1 & The fan with protection & 22,000 \\
\hline 2 & Ejector heat exchanger assembled & 3,000 \\
\hline 3 & Vessel for nitrogen supply & 5,000 \\
\hline 4 & Pipelines assembled & 2,000 \\
\hline 5 & Shutoff valves and devices of automatic equipment, and protection & 7,000 \\
\hline \multicolumn{2}{|l|}{ Total: } & 39,000 \\
\hline
\end{tabular}

Table 3 Operational costs during the installation work

\begin{tabular}{|l|l|}
\hline \multicolumn{1}{|c|}{ Operational costs } & Cost (UAH, per year) \\
\hline $\begin{array}{l}\text { Installation service (in } \\
\text { combination) }\end{array}$ & $3,000 * 12=36,000$ \\
\hline Cost of liquid nitrogen & $80 \mathrm{~g}$ per 1L petrol. \\
& $800 * 12=9,600$ \\
& $9,600 * 12=115,200$ \\
& (UAH) \\
\hline Electric power expense & $75 \mathrm{kvt} * 12=900$ \\
& $900 * 1.5=1,350$ \\
\hline Total: & 152,550 \\
\hline
\end{tabular}


The results of experiments have confirmed the relevance of application of nitrogen for cooling the flow of mix of air with hydrocarbons in the heat exchanger of the ejector, for condensation of hydrocarbons of different brands of gasolines, bioethanol and diesel fuel, and for their separation.

Application of the installation with the ejector heat exchanger for condensation of the low-boiling hydrocarbons at oil depot will provide protection of the environment from the vapors of hydrocarbons.

The drawn conclusions concerning the efficiency of LFT ejector system application are fair in case of connecting one of big reservoirs with gasoline to it. At the number of the connected reservoirs bigger than 5 the LFT ejector system may come out of competition.

Let's define what number of emissions is formed during functioning of the tank farm consisting of 8 reservoirs and annual turnover of oil equal to 300,000 tons.

The following designations and assumptions are accepted for calculation:

A tank volume is equal to $20,000 \mathrm{~m}^{3}$.

$B$ is the amount of liquid loaded into the reservoirs within a year, ton/year.

$M$ is the maximum emissions of pollutants into the atmosphere, $\mathrm{g} / \mathrm{s}$.

$G$ is annual emissions of pollutants into the atmosphere, ton/year.

$t_{n k}$ is the temperature of beginning of liquid boiling, ${ }^{\circ} \mathrm{C}$.

$T_{\min }, T_{\max }$ are temperatures respectively at maximum and minimum loading of liquid in the reservoir, ${ }^{\circ} \mathrm{C}$.

$N_{r}$ is the number of reservoirs, piece.

$P_{38}$ is pressure of saturated vapor of gasolines and oil at $T=38^{\circ} \mathrm{C}$.

$K_{t}^{\max }, K_{t}^{\min }$ are the experimental coefficients equal to 0.78 and 0.42 respectively.

$K_{p}^{c p}$ is the experimental coefficient equal to 0.62 .

$K_{o b}$ is the turnover coefficient.

$V_{h}^{\max }$ is the maximum volume of the vapor-air mixture which is forced out of the reservoirs during downloading, $\mathrm{m}^{3} / \mathrm{h}$.

$K_{B}$ is the experimental coefficient equal to 1.

$P$ is density of liquid, $\mathrm{t} / \mathrm{m}^{3}$.

Table 4. Data of a product.

\begin{tabular}{|l|l|l|l|l|l|l|l|}
\hline Product & $P_{38}, \mathrm{~mm} . \mathrm{m} . \mathrm{c}$. & $T,{ }^{\circ} \mathrm{C}$ & $T_{\min ,}{ }^{\circ} \mathrm{C}$ & $T_{\max },{ }^{\circ} \mathrm{C}$ & $V, \mathrm{~m}^{3} / \mathrm{h}$ & $B$, ton $/$ year & $P$, ton $/ \mathrm{m}^{3}$ \\
\hline Oil & 420 & 42 & 10 & 32 & 56 & 300,000 & 0.74 \\
\hline
\end{tabular}

Gross emissions of vapors of oil are calculated according to formulas (7) and (8) [4]:

- maximum emissions $(M, \mathrm{~g} / \mathrm{s})$ :

$$
M=\frac{0.163 \cdot P_{38} \cdot m \cdot K_{t}^{\max } \cdot K_{p}^{\max } \cdot K_{B} \cdot V_{h}^{\max }}{10^{4}}
$$

- annual emissions ( $G$, ton/year):

$$
G=0.294 \cdot P_{38} \cdot m \cdot\left(K_{t}^{\max } \cdot K_{B}+K_{t}^{\min }\right) \cdot K_{p}^{c p} \cdot K_{o b} \cdot B / 10^{7} .
$$

The maximum emissions and annual emissions will make:

$$
M=0.163 \cdot 420 \cdot 63.7 \cdot 0.78 \cdot 0.62 \cdot 1.0 \cdot 56 / 10^{4}=11.8100 \mathrm{~g} / \mathrm{s} .
$$




$$
G=0.294 \cdot 420 \cdot 63.7 \cdot(0.78 \cdot 1.0+0.42) \cdot 0.62 \cdot 1.35 \cdot 300000 / 10^{7}=237.0085 \text { ton/year }
$$

Thus, when functioning the tank farm consisting of 8 reservoirs and annual turnover of oil equal to 300,000 tons there are 237 tons of pollutants released into the atmosphere.

\title{
4. Conclusion
}

The existing processing equipment at the facilities of oil refinery often does not provide the necessary operating parameters even after optimization. And it is economically reasonable to implement the highly effective resourcesaving equipment.

In many cases along with increase in energy efficiency of such equipment there are also other important problems to be solved, i.e. decrease in metal capacity and increase in operating reliability and maintainability.

Summing up the results it should be noted that cost on design and acquisition of the equipment and also its mounting has made (UAH) 53,000. Annual operational costs have made (UAH) 152,550. Based on the carried-out calculations it is possible to claim that installation pays off less than in a year.

Implementation of the developed system of protection of the atmosphere based on trapping of light fractions of hydrocarbons of oil will provide reduction of losses of light fractions of oil to $98 \%$. It is 20 times less than annual emission of pollutants into the atmosphere from the reservoirs functioning without systems of trapping.

The advantages of the provided scheme is that there is no need in a separate pump which allows to reduce capital investments in system of trapping of light fractions at a stage of its implementation, and at its operation due to electric energy saving, minimization of servicing and increase in reliability of instruments for reduction of losses.

\section{References}

[1] Modeling of technology of trade preparation of oil / N. V. Usheva, A. V. Kravtsov, O. E. Moises, E. A. Kuzmenko//TPU News - 2005. - T. 308, No. 4 - page 127-130. (in Russian)

[2] V. Khmeliyuk, M. Kogut. Questions of safety during the transporting and storage oil products / Proc. of 7th Intern. sci.-techn. conf. "Modern problems of cooling equipment and technology ", Odessa, 2011, page 102. (in Ukrainian)

[3] RND 39.-142-00. A method of calculation of emissions of harmful substances in a circumambient from unorganized sources of the oil and gas equipment.

[4] RND 211.2.02.09-2004. Methodical directions for definition of emissions of pollutants in the atmosphere from reservoirs.

[5] Nysangaliyev A. N., Akhmedzhanov T. K., et al. Assessment of pollution of the atmosphere by gaseous substances from a one point and area sources. - Almaty: Hydrometeorology and ecology, 2001. - No. 3-4. - 177-181 pages. (in Russian)

[6] Patent of Ukraine "Method of hydrocarbon vapor condensation" No. 92548, 26.08 .2014 (in Ukrainian)

[7] Patent of Ukraine "Unit for condensation of hydrocarbon vapors in the stream" No. 92555, 26.08.2014 (in Ukrainian)

[8] V. Kogut, I. Butovskyi. Application of ejector heat exchangers in various industries \ East-European Journal of Advanced Technologies / Kharkiv - 2014 - Issue. 5, V. 1 (71) - p. 51-58

[9] Kogut, V. Application of heat exchange ejector for condensation of vapors of hydrocarbons [Text] / V. Kogut, I. Butovskyi, M. Khmelniuk // IV Intern. Sci. and Techn. Conf. "Kazakhstan-Refrigeration 2014”. Almaty, Kazakhstan, 2014. - P. 5-8.

\section{Енергоефективність холодильних ежекторних систем для конденсації рідких вуглеводнів нафтопродуктів}

\author{
Єгор Бутовський , Володимир Когут, Володимир Бушманов, Михайло Хмельнюк
}

Одеська Національна Академія Харчових технологій, Учбово-науковий інститут холоду, кріотехнологій та екоенергетики, вул. Дворяньска 1/3, Одеса, 65082, Украӥна

Підприємства переробки нафти $є$ найбільшим споживачем паливно-енергетичних ресурсів, теплоенергії та електричної енергії. Ефективність, раціональність їх використання в процесах переробки нафти багато в чому визначається загальною продуктивністю технологічного обладнання. Проте технологічні установки операційних підприємств, як правило, велика потужність, побудована в більшості випадків багато років тому, 
не відповідають сучасним вимогам до якості продукту, безпеці, рівнем автоматизації управління процесами тощо. Особливість обробки вуглеводневої сировини - технологічні процеси недосконалі. Тому одним із пріоритетних напрямків підвищення ефективності економії енергоносіїв нафтопереробки $є$ максимальне використання відновлення теплоти та оптимізація режимів роботи технологічних установок. У багатьох випадках разом із підвищенням теплової ефективності такого обладнання також вирішуються не менш важливі проблеми: зменшення споживання металу, підвищення надійності та простоти експлуатації. У статті увага зосереджена на використанні холодильних ежекторних систем у вирішенні найважливіших проблем галузі нафтопереробки. Запропоновані системи дозволяють ефективно вирішувати питання економії енергії та раціонального споживання паливно-енергетичних ресурсів підприємств нафтодобувної промисловості. Ці схеми рішень в галузі є пріоритетним напрямом політики економії енергії.

Ключові слова: холодильні ежекторні системи; рідкі вуглеводні; енергетична ефективність; енергозбереження; вуглеводнева сировина. 